\title{
EFFICIENCY OF THE PARASITOID Coccophagus Scutellaris (DALMAN) AND SOME INSECTICIDES AGAINST THE SOFT SCALE INSECT Pulvinaria tenuivalvata (NEWSTED) IN SUGARCANE FIELDS AT ASWAN GOVERNORATE, EGYPT. Shalaby, M. S. I.; H. A. Saleh and A. E. Hatem. \\ Plant Protection Research Institute, Agriculture Research Center, Dokki, Egypt.
}

\begin{abstract}
The present investigation was carried out at Awadlab village-Edfu district, Aswan Governorate during 2003\& 2004 seasons to magnifying the role of parasitoid Coccophagus scutellaris (Dalman ) as element from (IPM) and evaluated seven insecticide from different groups for control the soft scale insect Pulvinaria tenuivalvata (Newsted) in sugarcane fields. The obtained results clearly showed that, percentage of parasitism significantly increased from $17.64 \%$ before release to $60.44 \%$ after release in the $1^{\text {st }}$ season while in the $2^{\text {nd }}$ season increased from $27.45 \%$ to $73.88 \%$, also percentage of estimated parasitism recorded $32.62 \% \& 37.87 \%$ in the $1^{\text {st }} \& 2^{\text {nd }}$ seasons respectively. On the other hand in the $1^{\text {st }}$ season the highest effect after15 days and 30 days in total individual (nymph \& adult) observed in Actellic $(95.77 \%$ \& $98.21 \%)$ flowed by Malathio $(91.47 \%$ \& $95.63 \%)$, Sulfur $(89.01 \%$ \& 94.37\%) , Admiral(88.94\% \& 93.86\%) (Malathion+ Sulfer) (87.86 \% \& $94.37 \%)$ Agrieen (86.52\% \& 92.11\%) and Manf( $84.81 \%$ \& $89.59 \%$ ) respectively, while in the $2^{\text {nd }}$ season the data showed that the highest effect after 15 days in total individual (nymph \& adult) observed in Actellic which recorded $95.55 \%$ followed by Malathion, Sulfer, Admiral, Agrieen , (Malathion + Sulfer ) and manf which recorded $91.33 \%$, $87.96 \%, 87.51 \%, 86.17 \%, 85.33 \%$ and $84.71 \%$ respectively. while after 30 days the highest one was Actellic which recorded $98.3 \%$ followed by Sulfer, Malathion, Agrieen, Admiral, (Malathion+ Sulfer) and manf which recorded $94.79 \%, 94.71 \%$, $94.61 \%, 94.36 \%, 93.44 \%$ and $92.2 \%$ respectively.
\end{abstract}

\section{INTRODUCTION}

Sugarcane ( Saccharum officinarum L.) is one of the most important sources of sugar production that should be grown in large scale in tropical and sub tropical countries. In Egypt sugarcane is the second most important economic crop, cultivated area about 312 thousand feddans. Numerous and serious pests infesting sugarcane plants and cause a lot of damage which affect sugarcane yield and juice quality, the main piercing sucking insect the red striped soft scale Pulvnaria tenuivlvata (Newstead), Watson \& Foldi, (2001) are considered recently the key pests of sugarcane production in Egypt.

The pest suck the cell of the leaves and excrete a large of honeydew, that cover plant leaves and encourages the growth of sooty mould fungus which give the infested plants dirty blake appearance that effect on photosynthesis and respiration processes of sugarcane plants Ali et et al., (2000) , Shalaby, (2002) and Saleh, (2005). This pest in the field infected by 
Coccophagus scutellaris (Dalman) which was parasitism on the soft scale insect $P$. tenuivalvata cased reduced in population of nymphal and adults stages in sugarcane field Hendawy et al., (2002). Shalaby, (2002) and Abd El-Samea (2003).

Under severe attack, the pest caused economic loss in both sugarcane quantity(yield) and quality (juice extraction) so that the present study directed to estimated seven insecticide against $P$. tenuivalvata

The aim of this study to evaluate the role of the parasitoid C. scutellaris in reduced the pest population and estimated seven chemical compounds from different groups for control the soft scale insects $P$. tenuivalvata in sugar cane fields.

\section{MATERIALS AND METHODS}

\section{1-Distribution of parasitoid.}

An area about one feddan were cultivated by $C 9 / 54$ sugarcane variety at Awadlab village-Edfu district, Aswan Governorate in November 2003 (first ratoon) while in the second, it was in August 2004 (second ratoon)this area were infested with soft scale insect, $P$. tenuivalvata about half feddan was chosen to be a treatment. Another half feddan, far with about $500 \mathrm{~m}$ from the treatment, was also chosen to be a control. Each of both areas was divided into four equal plots $525 \mathrm{~m}^{2}$ for each. An infested sugarcane field was chosen to collect leaves with scale insects hosted black color stage of parasitoid. The leaves were transferred to the laboratory and kindly tested to remove all uninfested scales. A group of 1000 infected insects was randomly distributed, in each specialized area in the treatment, as 3-5 insects per plant. One month later, 100 leaves were randomly collected from each plot in the control or in the treatment to count numbers of infected and uninfected scales.

Estimated increase in the parasitism was calculated as follows:

$$
\% \text { increase }=\left(\mathbf{T}_{\mathrm{a}}-\mathbf{T}_{\mathrm{b}}\right)-\left(\mathbf{C}_{\mathrm{a}}-\mathbf{C}_{\mathrm{b}}\right)
$$

Whereas: $T_{a}=\%$ parasitism in the treatment after releasing

$\mathrm{T}_{\mathrm{b}}=\%$ parasitism in the treatment before releasing

$\mathrm{C}_{\mathrm{a}}=\%$ parasitism in the control after releasing

$\mathrm{C}_{b}=\%$ parasitism in the control before releasing

\section{2-Chemical control}

This experiments carried out at Awadlab village-Edfu district, Aswan Governorate to evaluate the efficiency of seven insecticides from deferent groups to control of the soft scale insects in sugarcane field compared with untreated treatment (Chick) .this insecticides were tabulated in next table 
Table (1): List of evaluated insecticides in Awadlab village at Edfu district, Aswan Governorate during 2003/2004 seasons.

\begin{tabular}{|c|c|c|c|c|}
\hline No. & Trade name & Common name & $\begin{array}{l}\text { Pesticide } \\
\text { group }\end{array}$ & Rate of application \\
\hline 1 & Actellic $50 \%$ Ec & $\begin{array}{c}\text { Pirimiphos- } \\
\text { methel }\end{array}$ & OP & $150 \mathrm{ml} / 100$ liter of water \\
\hline 2 & Malathion 57\%EC & Malathion & OP & $250 \mathrm{ml} / 100$ liter of water \\
\hline 3 & Malathion +Sulfur & $\begin{array}{l}\text { Malathion + } \\
\text { Sulfur }\end{array}$ & $\begin{array}{l}\mathrm{OP}^{*} \text { Natural } \\
\text { (Mixed-up) }\end{array}$ & $\begin{array}{c}100 \mathrm{ml}(\text { Malathion })+400 \mathrm{~g} \text { (Sulfur)ml } \\
/ 100 \text { liter of water }\end{array}$ \\
\hline 4 & Sulfur 30\%EC & Sulfur & Natural & Liter/100 liter of water \\
\hline 5 & Agrieen & Agrieen & $\mathrm{Bio}(\mathrm{BT})$ & $250 \mathrm{~g} / 100$ liter of water \\
\hline 6 & Manf (6) $10 \%$ Ec & Manf & Natural Oils & $300 \mathrm{ml} / 100$ liter of water \\
\hline 7 & Admiral $10 \% E C$ & Pyriproxyfen & $\begin{array}{c}\text { Juvenile } \\
\text { hormone } \\
\text { mimic }\end{array}$ & $50 \mathrm{ml} / 100$ liter of water \\
\hline
\end{tabular}

This treatment were percent in $1680 \mathrm{~m}^{2}$ were cultivated by the commercial variety C9/54, in November 2003 (first ratoon) while in the second, it was in August 2004 (second ratoon) randomized complete block design with three replicates $70 \mathrm{~m}^{2}$ for each, all the experimental plots received the normal agricultural treatments, the samples were picked up to random with rate of 10 leaves/ replicate ( 40 leaves /treatment ) before spraying then after 15 and 30 days of spraying. The collected samples transferred to laboratory in paper pages and inspected, nymphs and adults were counted and recorded.

Percent of reduction in the soft scale insect population was estimated using Henderson and Tilton equation (1955) to determine the effect after 15 days and the effect after 30 days intervals. All the statistical analyses of the present work were conducted using COSTAT computer program.

\section{RESULTS AND DISCUSSION}

\section{1-Effect of parasitoid in decreasing P.tenuivalvata number}

Effect of released the parasitoid $C$. scutellaris in sugarcane fields to determine the role of parasitoid as element of protection the crop from the soft scale insect during two successive seasons are shown in Table (2). The data evident that, in $1^{\text {st }}$ season the percent of parasitism recorded $17.64 \%$ in treatment before the releasing while in control recorded $20.93 \%$ this value increased significantly after the releasing which recorded $60.44 \%$ and $31.11 \%$ in treatment and control respectively, the same trend was evident in the $2^{\text {nd }}$ season which recorded $27.45 \%$ in treatment and $25.67 \%$ in control before the releasing this value increased after the releasing which recorded $73.8 \%$ and $34.24 \%$ in treatment and control respectively. On the other hand the data in the same table evident that, the releasing process increased the number of parasitoids in the distribution area of parasitoids more than the natural parasitoids which were 182 (in treatment) and 129 (in natural) before releasing, this number increasing significantly after releasing which recorded 970 (in treatment) and 298 (in the chick) in the $1^{\text {st }}$ season. The data showed the same trained in the $2^{\text {nd }}$ season which were 395 (in treatment) and 337 (in natural) before releasing this number increasing significantly after releasing which recorded 1930 in treatment and 809 in natural. 
Table (2) : Percent of parsitism in the P.tenuivalvata at Aswan Governorate during 2003 \& 2004 seasons

\begin{tabular}{|c|c|c|c|c|c|c|c|}
\hline \multirow[t]{2}{*}{ Seasons } & \multirow[t]{2}{*}{ Releasing } & \multirow[t]{2}{*}{ Area } & \multicolumn{2}{|c|}{$\begin{array}{c}\text { No. soft } \\
\text { scale/100 leaf }\end{array}$} & \multirow[t]{2}{*}{$\begin{array}{c}\% \\
\text { prasitism }\end{array}$} & \multirow{2}{*}{$\begin{array}{l}\text { Total no. } \\
\text { parasitism }\end{array}$} & \multirow{2}{*}{$\begin{array}{c}\% \text { of } \\
\text { Estimated } \\
\text { parasitism }\end{array}$} \\
\hline & & & Total & Infected & & & \\
\hline \multirow{4}{*}{2003} & \multirow[t]{2}{*}{ Befor } & Treat. & 578 & \begin{tabular}{|l|}
102 \\
\end{tabular} & 17.64 & 182 & \multirow{4}{*}{32.62} \\
\hline & & control & 387 & 81 & 20.93 & 129 & \\
\hline & \multirow[t]{2}{*}{ After } & Treat. & 852 & 515 & 60.44 & $970_{a}$ & \\
\hline & & control & 646 & 201 & 31.11 & $298 b$ & \\
\hline \multirow{4}{*}{2004} & \multirow[t]{2}{*}{ Befor } & Treat. & 783 & 215 & 27.45 & 359 & \multirow{4}{*}{37.78} \\
\hline & & control & 701 & 180 & 25.67 & 337 & \\
\hline & \multirow[t]{2}{*}{ After } & Treat. & 1470 & 1088 & 73.88 & $1930 \mathrm{a}$ & \\
\hline & & control & 1241 & 425 & 34.24 & $809 b$ & \\
\hline
\end{tabular}

Calculated T. value $=17.20(2003)$ season. Calculated T. value $=13.75(2004)$ season.

Aim from this work magnifies the role of the parasitoid C. scutellaris against the soft scale insects of sugarcane in fields. It cleared significant increased in the infected scales population recorded a maximum of $60.44 \%$ and $73.8 \%$ in the two seasons, respectively. The estimated increase in the parasitism due to release ranged between $32.62 \%$ in the $1^{\text {st }}$ season and $37.78 \%$ in the $2^{\text {nd }}$ one.

Paramonova et al., (1984) reported that $50 \%$ of females and $56 \%$ of larvae of Pulvinaria ribesiae were infected with parasite complex. Also Shalaby (2002) reported that, in 1997 sugarcane season the rate of parasitism with $C$. scutellaris in $P$. tenuivalvata population was $22.2 \%$ in July, $33.3 \%$ in September and 60.15\% in August. In 1998 sugarcane season, Abdrabou (2002) reported 26 and $22 \%$ only as a maximum parasitism in Saissetia coffeae (Walker) and S. oleae (Olivier) with the same parasitoid, respectively. In the same time, the releasing not only increased the parasitism percentages but also increased the mean number of parasitoid per a host, while it ranged $1.19-1.29$ in the natural infestation, it raised to $1.57-$ 1.82 after releasing. In this respect, Abd-El Samea (2003) recorded $1-10$ parasitoids emerged from one host according to the stage in the laboratory.

\section{2-Effect of some insecticides in decreasing $P$. tenuivalvata number}

Evaluate the efficiency of seven insecticides from different groups and check to control of the soft scale insect P.tenuivalvata in sugarcane field during 2003 and 2004 seasons tabulated in Tables ( $3 \& 4$ ) the data showed that, the population of nymphs, adults and total individual of P.tenuivalvata as well as effect of tested insecticides after 15 days of application and the effect after 30 days of application. In the $1^{\text {st }}$ season the data showed in Table (3) and indicated that, the highest effect after 15 days on nymph population recorded in Actellic flowed by Malathion, Sulfur and Admiral which recorded highest of reduction reached to $(96.22 \%),(92.57 \%),(90.29 \%)$ and $(90.03 \%)$ respectively, whereas the other tested insecticides recorded less effective, Malathion+ Sulfer (89.71\%) Agrieen (89.87\%), and Manf( $87.9 \%)$ respectively, while Actellic was the highest one in case of adult population 
which recorded (94.54\%) fowloed by Malathion ,Sulfur, Admiral, Malathion+ Sulfur , Agrieen and Manf which recorded (91.1\%),( 85.4\%), ( 83.8\%), $(81.1 \%),(77.02 \%)$, and $(69.85 \%)$ respectively. On the other hand the effect after 30 days of the tested insecticides on the nymph and adult population were recorded in the same Table which showed that, the highest reduction of nymph population were in Actellic (98.5\%) followed by Malathion, , Sulfer, Admiral, Malathion + Sulfsr, Agrieen and Manf which recorded (95.94\%), (94.24\%), (94.74\%), (94.19\%), (93.69\%) and (92.7\%) respectively while in the adult population Actellic was the highest one which recorded ( $97.37 \%$ ) followed by Malathion, Sulfur, Admiral, Malathion+Sulfur, Agrieen, and Manf which recorded $(94.86 \%),(91.99 \%),(91.24 \%),(87.69 \%),(85.58 \%)$ and $(73.45 \%)$ respectively,

Statistical analysis of data showed the highly significant differences between chick treatment and all tested insecticides but not found significant deference between tested insecticides.

The efficiency of the tested insecticides was clear in the same Table the data evident that, an average percent of reduction which recorded the highest value in Actellic which were $(96.99 \%)$ followed by Malathion (93.55\%), Sulfur (91.69\%), Admiral(91.17\%), Malathion+Sulfur (90.35\%), Agrieen(89.31\%) and the last one Manf which recorded $(87.2 \%)$. The data in the $2^{\text {nd }}$ season showed in Table (4) and indicated that, the highest effect after 15 days on nymph population recorded in Actellic flowed by Malathion, Admiral and Sulfur which recorded highest of reduction reached to $(96.06 \%),(92.31 \%)$, $(90.44 \%)$ and $(90.38 \%)$ respectively, whereas the other tested insecticides recorded less effective, Agrieen (89.87\%), Malathion+ Sulfer (88.04\%)and Manf( $87.92 \%)$ respectively, while Actellic was the highest one on adult population which recorded (95.16\%) fowloed by Malathion ,Sulfur, Admiral, Malathion+ Sulfur, Manf and Agrieen which recorded (90.65\%), (83.16\%), $(81.69 \%),(80.14 \%),(77.53 \%)$, and $(76.51 \%)$ respectively. On the other hand the effect after 30 days of the tested insecticides on the nymph and adult population were recorded in the same table which showed that, the highest reduction of nymph population were in Actellic (98.46\%) followed by Malathion, Agrieen, Sulfer, Admiral, Malathion + Sulfsr and Manf which recorded (96.73\%), (96.22\%), (95.72\%), (95.54\%), (94.77\%) and (93.4\%) respectively, while in the adult population Actellic was the highest one which recorded $(98.35 \%)$ followed by Sulfur, Admiral, Malathion Agrieen, Malathion+Sulfur, and Manf which recorded (93.52\%) , (92.7\%), (92.47\%), $(91.56 \%),(91.29 \%)$ and $(90.86 \%)$ respectively, Statistical analysis of data showed the highly significant differences between chick treatment and all tested insecticides but not found significant deference between tested insecticides. 
Shalaby, M. S. I. et al.

T 3 
J. Agric. Sci. Mansoura Univ., 33 (1), January, 2008

$\mathrm{T} 4$ 
The efficiency of the tested insecticides was clear in the average percent of reduction which recorded the highest value in Actellic which were $96.92 \%$ followed by Malathion (93.02\%) Sulfur (91.37\%) Admiral (90.93\%) Agrieen $(90.39 \%)$ Malathion+Sulfur (89.38\%) and the last one Manf which recorded (88.45\%).

Many authors data agreed with the above mentioned data they showed that, Admiral $10 \%$ EC with rate $0.05 \%$ gave $83.3 \%$ reduction after 6 weeks of application against Parlatoria oleae infesting plum tree in wadi El-natrun ( ElImery et al.1999) whereas, Helmy et al.(2002) showed that $80.3 \%$ reduction percentages in Ceroplastes floridensis Comstock and Aonidiella aurantii (Maskell) population on navel orange tree in Qalubiya Governorate. Tawfik, et al. (2002) showed that, Admiral $10 \%$ EC at rate $0.05 \%$ gave $89.2 \%$ reduction percentage in the population of Aonidiella aurantii on acid less orange in BniSwaif Governorate whereas , El-Amir (2002) showed that Admiral 10\% EC at rate $0.05 \%$ gave $96.1 \%$ reduction after 3 months of application agents Parlatoria oleae on olive trees in Ismailia governorate.

EIWan et al. (2005a) evaluated the efficiency of six organophosphorus insecticide for control $P$. tenuivalvata on sugarcane fields in Naga-Hammadi district, Qena Governorate and showed that, Actellic 50\% EC, Sumithion 50 $\%$ EC Dursban $48 \%$ EC and Dimethoate $40 \%$ EC ( at rate of .15\% for each one ) reduced the insect population ( Nymphs and adults ) to $98.7 \%, 98.1 \%$ , $96.6 \%$ and $95.8 \%$, respectively. Whereas Malatox $50 \% \mathrm{Wp}$ at rate $0.3 \%$ gave reduction percentage of $95.7 \%$ and Malathion $57 \%$ EC at $0.25 \%$ reduced the population to $95.3 \%$.

EIWan et al. (2005b) evaluated the efficiency of seven insecticide for control P. tenuivalvata on sugarcane fields in Kom-Ombo district, Aswan Governorate and showed that, Chalinger was the highest effective compound on the nymphal populations $94.8 \%$.Admiral and Mospilan came in the $2^{\text {nd }}$ order $(93.6 \%$ and $93.4 \%)$ followed by Marshal in $3^{\text {rd }}$ order $(88.9 \%)$. sulfer \& Actara came in the $4^{\text {th }}$ order $(88.1 \% \& 88 \%)$ and Orion was the last one 86.8\%). Moreover, Chalinger Admiral and Mospilan were the highest effective compound on the adult populations 93.5,92.5 and 91.9 followed by Marshal in $2^{\text {nd }}$ order $(86.6 \%)$. sulfer \& Actara and Orion were less effective pesticide on adult populations ( $85.6,84.6$ and 83.5 ).

\section{REFERENCES}

Abd El-samea, S. A. (2003): Laboratory studies on the Coccophagus scutellaris (Dalman) (Hymenoptera: Aphelinidae), parasitoid of the soft scale insect, Pulvinaria tenuivalvata, apest of sugar cane in Egypt. Egypt. J. Agric. Res., 81 (3) :967-976.

Abd-Rabou, S. (2002):The role of Coccophagus scutellaris (Hymenoptera: Aphelinidae) in the biological control of soft scale insects (Homoptera: Coccidae) in Egypt. Entomologia Sinica 9 (3): 39-44.

Ali, M. A.; El-Khouly, A.S.; El-Metwally, F. El-M., Shalaby, M.S.I. (2000): Occurrence, distribution and host range of the sugarcane soft scale, Pulvinaria tenuivalvata (Newstead) in upper Egypt. Bull. Ent. Soc. Egypt, ( 78 ): 243-250. 
El-Amir, S. E. (2002): Environmentally safe approaches for controlling some scale insects infesting olive tree in new reclaimed areas. M. Sc. Thesis Institute of Environmental studies \& Research, Ain Shams Univ.pp . 84.

El-Imery,S. M. ; G. H. Sewif ; M. F. Twfik and N. A. Ezz. (1999): Bio- residual effect of some scalicides on the plum scale insect Palatoria oleae (Colvee) and its parasitoid Aphytis sp $2^{\text {nd }}$ Int. Conf. of Pest. Control, Mansoura, Egypt, 6 -8 Sep.:199-204

Elwan, E. A ; M. S. I. Shalaby; M. M. Khewa and (2005a) :Efficiency of some insecticide for controlling Pulvinaria tenuivalvata (Newstead) (Homoptera : Coccidae) on sugarcane in Naga-Hammadi district Qena governorate. Egypt. J. Agric. Res., 83(4):1649-1661

Elwan, E. A ; S. M. Assem ; M. M. Khewa and M. S. I. Shalaby $\left(2005^{b}\right)$ :Field Evaluation of some pesticide for controlling Pulvinaria tenuivalvata (Newstead) (Homoptera : Coccidae) on sugarcane in Kom Ombo district Aswan governorate. Egypt. J. Agric. Res., 83(4):1669-1679

Helmy, E. I. ; N. A. Hassan, F. A. Kwaiz and O. N. EL Sahn. (2002): Effect of IGR, Miscble oil, their joint effect compared with OP compound on hard and wax scale insects infesting citrus at Qalubiya governorate, Egypt $1^{\text {st }}$ Conf. of the Central Agric. Pesticide Lab., 3-5 Sep. : 741-746.

Hendawy, A. S; El-Mitwally, M. F. and Abd El-samea, S. A. (2002): Scientific note:Coccophagus scutellaris (Dalman) (Hymenoptera: Aphelinidae), a new record parasitoid attacking sugar-cane soft scale insect, Pulvinaria tenuivalvata (Newstead) in Egypt. Egypt. J. Agric. Res., 80 (1) 219-222.

Henderson, C. F. and E. W. Tilton. (1955): Test with acaricides against the brown wheat mite. J. Econ. Entomol.,(48):157-161.

Khewa,M.M. (2005): Maximizing the parasitism role of Coccophagus scutellaris against the soft scale insect;Pulvinaria tenuivalvata Newsted)(Homoptera:Coccidae) in egyption sugarcane fields. The $3^{\text {rd }}$ Int. Conf. of plant protection research institute 26-29 Nov.2005

Paramonova, O. V; Saakyan- Baranova, A.A. and Baranova, A.A. Saakyan (1984): The black currant scale Pulvinaria ribesiae Sign (Homoptera: Coccidae) and its parasites in Byelorussia. Entomologicheskoe Obozrenie. 63 (2) 250-258.

Saleh, H. A (2005): Impact of the Red striped soft scale insect, Pulvinaria tenuivalvata (Newsted) Infestation on the quantity and quality plant of sugarcane under cultural practices. Ph.D. Thesis, Fac. Agric., Cairo Univ.,pp.134.

Shalaby, M. S. I (2002): Ecological and biological studies on the sugarcane scale Pulvinaria tenuivalvata (Newsted) infesting sugarcane in giza governorate. Ph.D. Thesis,Fac.Agric.,Al-Azhar Univ.Cairo,pp.208.

Tawfik, M.H.; M. A. Asfoor and G. H. Mohammed.(2002) : The effect of summer spray materials on red scale insect, Aonidiella aurantii (Mask) (Homoptera: Diaspididae), side effect on host plant and associated parasitoid. The 2nd Int. Conf. of plant protection research institute 2124 Des., : 886-869.

Watson, G. W. and I. Foldi. (2001): The identify of red striped soft scale on sugarcane in Egypt, Pulvinaria tenuivalvata (Newsted) ( Hemiptera : Coccidae). Bull. Ent. Soc.Egypt, (79) :37- 42. 


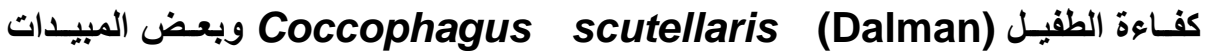

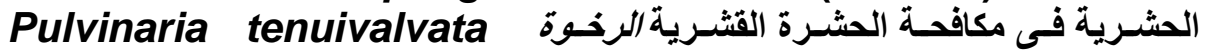
في حقول قصب السكر بمحافظة اسوان (newsted)

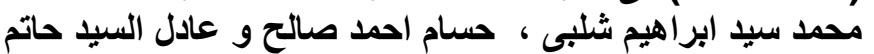

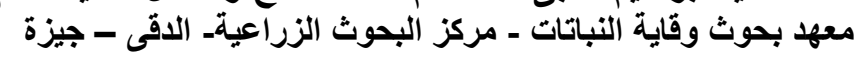

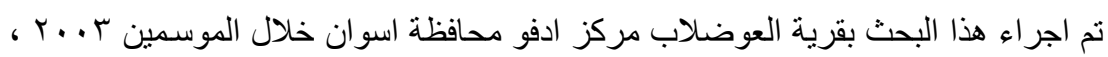

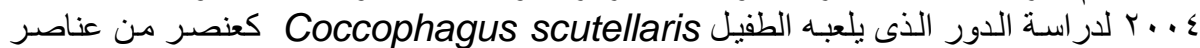

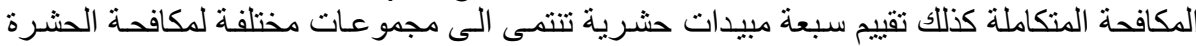

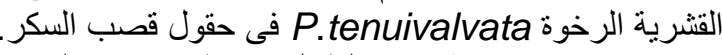

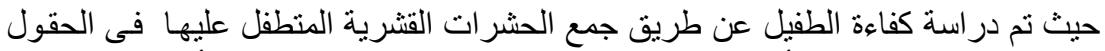

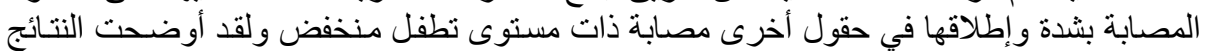

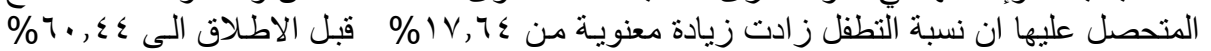

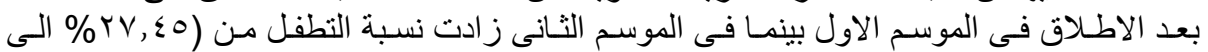

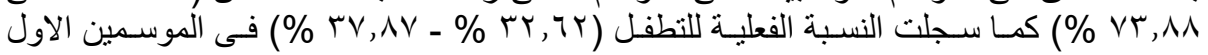

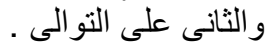

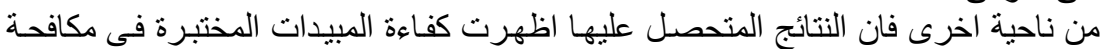

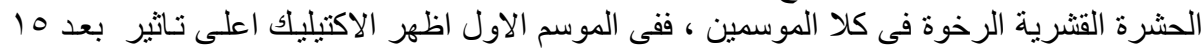

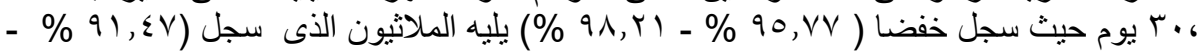

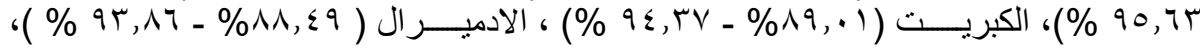
مخلوط الملاثيون مع الكبريت (1) (

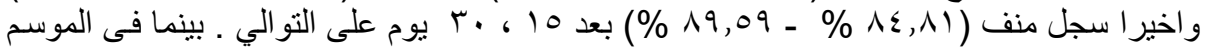

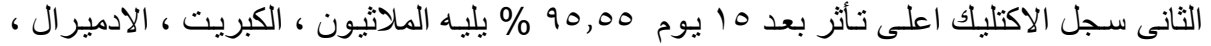

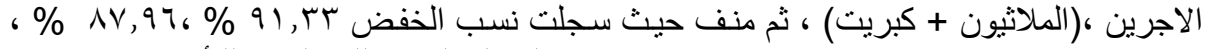

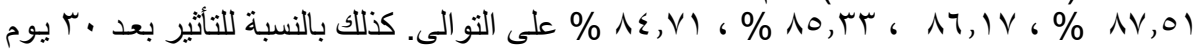

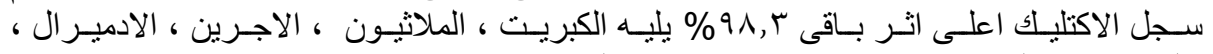

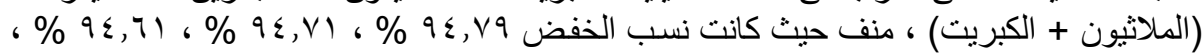

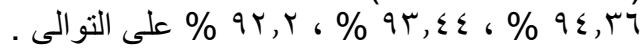


Table (3 ): Efficiency of some insecticides on the soft scale insect, $P$. tenuivalvata infested sugarcane plants in Awadlab village at Edfu district,Aswan Governorate in 2003 season

\begin{tabular}{|c|c|c|c|c|c|c|c|c|c|c|c|c|}
\hline \multirow[b]{2}{*}{ Insecticides } & \multicolumn{3}{|c|}{ Pre-spraying count } & \multicolumn{3}{|c|}{ Initial effect after 15 days } & \multicolumn{3}{|c|}{$\begin{array}{c}\text { Residual effect after } 30 \\
\text { days }\end{array}$} & \multicolumn{3}{|c|}{$\begin{array}{l}\text { Average percent of } \\
\text { reduction }\end{array}$} \\
\hline & Nymphs & Adults & Total & Nymphs & Adults & Total & Nymphs & Adults & Total & Nymphs & Adults & Total \\
\hline \multirow[t]{2}{*}{ Actellic50\%Ec } & \multirow[t]{2}{*}{1214} & \multirow[t]{2}{*}{462} & \multirow[t]{2}{*}{1676} & $57 \mathrm{~b}$ & $23 \mathrm{~b}$ & 80 & $24 \mathrm{~b}$ & $13 \mathrm{~b}$ & 37 & 40.5 & 18 & 58.5 \\
\hline & & & & 96.22 & 94.54 & 95.77 & 98.5 & 97.37 & 98.21 & 97.36 & 95.95 & 96.99 \\
\hline \multirow[t]{2}{*}{ Malathion 57\% Ec } & \multirow{2}{*}{1101} & \multirow{2}{*}{382} & \multirow[t]{2}{*}{1483} & $112 \mathrm{~b}$ & $31 \mathrm{~b}$ & 143 & $59 \mathrm{~b}$ & $21 \mathrm{~b}$ & 80 & 85.5 & 26 & 111.5 \\
\hline & & & & 92.57 & 91.1 & 91.47 & 95.94 & 94.86 & 95.63 & 94.25 & 92.98 & 93.55 \\
\hline \multirow[t]{2}{*}{ Malathion + Sulfer } & \multirow[t]{2}{*}{1096} & \multirow[t]{2}{*}{296} & \multirow[t]{2}{*}{1392} & $140 \mathrm{~b}$ & $51 \mathrm{~b}$ & 191 & $84 \mathrm{~b}$ & $39 \mathrm{~b}$ & 123 & 112 & 45 & 147 \\
\hline & & & & 89.71 & 81.1 & 87.86 & 94.19 & 87.69 & 92.84 & 91.95 & 83.39 & 90.35 \\
\hline \multirow[t]{2}{*}{ Sulfer $30 \% \mathrm{~L}$} & \multirow[t]{2}{*}{813} & \multirow[t]{2}{*}{338} & \multirow[t]{2}{*}{1151} & $98 \mathrm{~b}$ & $45 \mathrm{~b}$ & 143 & $51 \mathrm{~b}$ & $29 \mathrm{~b}$ & 80 & 74.5 & 37 & 111.5 \\
\hline & & & & 90.29 & 85.4 & 89.01 & 95.24 & 91.99 & 94.37 & 92.76 & 88.69 & 91.69 \\
\hline \multirow[t]{2}{*}{ Agrieen } & \multirow[t]{2}{*}{1093} & \multirow[t]{2}{*}{272} & \multirow[t]{2}{*}{1365} & $151 \mathrm{~b}$ & $57 \mathrm{~b}$ & 208 & $91 \mathrm{~b}$ & $42 \mathrm{~b}$ & 133 & 121 & 49.5 & 170.5 \\
\hline & & & & 88.87 & 77.02 & 86.52 & 93.69 & 85.58 & 92.11 & 91.28 & 81.3 & 89.31 \\
\hline \multirow[t]{2}{*}{ Manf } & \multirow[t]{2}{*}{1018} & \multirow[t]{2}{*}{211} & \multirow[t]{2}{*}{1229} & $153 \mathrm{~b}$ & $58 \mathrm{~b}$ & 211 & $98 \mathrm{~b}$ & $60 \mathrm{~b}$ & 158 & 125.5 & 59 & 184.5 \\
\hline & & & & 87.9 & 69.85 & 84.81 & 92.7 & 73.45 & 89.59 & 90.3 & 71.65 & 87.2 \\
\hline \multirow[t]{2}{*}{ Admiral 10\%Ec } & \multirow[t]{2}{*}{994} & \multirow[t]{2}{*}{352} & \multirow[t]{2}{*}{1346} & $123 \mathrm{~b}$ & $52 \mathrm{~b}$ & 175 & $69 \mathrm{~b}$ & $33 \mathrm{~b}$ & 102 & 96 & 42.5 & 138.5 \\
\hline & & & & 90.03 & 83.8 & 88.49 & 94.74 & 91.24 & 93.86 & 92.38 & 87.52 & 91.17 \\
\hline Control & 1044 & 534 & 1578 & $1297 \mathrm{a}$ & $487 \mathrm{a}$ & 1784 & 1378 a & $572 \mathrm{a}$ & 1950 & 1337.5 & 529.5 & 1867 \\
\hline F value & & & & $92.11^{* *}$ & $126.12^{\star \star}$ & & $254.44^{\star *}$ & $128.52^{\star *}$ & & & & \\
\hline LSD at 0.05 & & & & 43.99 & 14.1 & & 29.39 & 17.01 & & & & \\
\hline
\end{tabular}


Table (4): Efficiency of some insecticides on the soft scale insect, $P$. tenuivalvata infested sugarcane plants in Awadlab village at Edfu district,Aswan Governorate in 2004 season

\begin{tabular}{|c|c|c|c|c|c|c|c|c|c|c|c|c|}
\hline \multirow[b]{2}{*}{ Insecticides } & \multicolumn{3}{|c|}{ Pre-spraying count } & \multicolumn{3}{|c|}{ Initial effect after 15 days } & \multicolumn{3}{|c|}{$\begin{array}{c}\text { Residual effect after } 30 \\
\text { days }\end{array}$} & \multicolumn{3}{|c|}{$\begin{array}{l}\text { Average percent of } \\
\text { reduction }\end{array}$} \\
\hline & Nymphs & Adults & Total & Nymphs & Adults & Total & Nymphs & Adults & Total & Nymphs & Adults & Total \\
\hline \multirow[t]{2}{*}{ Actellic50\%Ec } & \multirow[t]{2}{*}{1296} & \multirow[t]{2}{*}{426} & \multirow[t]{2}{*}{1676} & $60_{b}$ & $20 \mathrm{~b}$ & 80 & $25 \mathrm{~b}$ & $8 \mathrm{~b}$ & 33 & 42.5 & 14 & 56.5 \\
\hline & & & & 96.06 & 95.16 & 95.55 & 98.46 & 98.35 & 98.3 & 97.26 & 96.75 & 96.92 \\
\hline \multirow[t]{2}{*}{ Malathion 57\% Ec } & \multirow[t]{2}{*}{1095} & \multirow[t]{2}{*}{397} & \multirow[t]{2}{*}{1492} & $99 \mathrm{~b}$ & $36 \mathrm{~b}$ & 135 & $45 \mathrm{~b}$ & $34 \mathrm{~b}$ & 89 & 72 & 35 & 107 \\
\hline & & & & 92.31 & 90.65 & 91.33 & 96.73 & 92.47 & 94.71 & 94.52 & 91.59 & 93.02 \\
\hline \multirow[t]{2}{*}{ Malathion + Sulfer } & \multirow[t]{2}{*}{1032} & \multirow[t]{2}{*}{332} & \multirow[t]{2}{*}{1364} & $145 b$ & $64 \mathrm{~b}$ & 209 & $68 \mathrm{~b}$ & $33 b$ & 101 & 106.5 & 48.5 & 155 \\
\hline & & & & 88.04 & 80.14 & 85.33 & 94.77 & 91.29 & 93.44 & 91.4 & 85.7 & 89.38 \\
\hline \multirow[t]{2}{*}{ Sulfer $30 \% \mathrm{~L}$} & \multirow[t]{2}{*}{929} & \multirow[t]{2}{*}{312} & \multirow[t]{2}{*}{1241} & $105 b$ & $51 \mathrm{~b}$ & 156 & $50 \mathrm{~b}$ & $23 b$ & 73 & 77.5 & 37 & 114.5 \\
\hline & & & & 90.38 & 83.16 & 87.96 & 95.72 & 93.52 & 94.79 & 93.05 & 88.34 & 91.37 \\
\hline \multirow[t]{2}{*}{ Agrieen } & \multirow[t]{2}{*}{1008} & \multirow[t]{2}{*}{307} & \multirow[t]{2}{*}{1315} & $120 \mathrm{~b}$ & $70_{b}$ & 190 & $48 b$ & $32 b$ & 80 & 84 & 51 & 135 \\
\hline & & & & 89.87 & 76.51 & 86.17 & 96.22 & 91.56 & 94.61 & 93.04 & 84.03 & 90.39 \\
\hline \multirow[t]{2}{*}{ Manf } & \multirow[t]{2}{*}{986} & \multirow[t]{2}{*}{298} & \multirow[t]{2}{*}{1284} & $140 \mathrm{~b}$ & $65 \mathrm{~b}$ & 205 & $82 b$ & $31 b$ & 133 & 111 & 48 & 159 \\
\hline & & & & 87.92 & 77.53 & 84.71 & 93.4 & 90.86 & 92.2 & 90.6 & 84.19 & 88.45 \\
\hline \multirow[t]{2}{*}{ Admiral 10\%Ec } & \multirow[t]{2}{*}{908} & \multirow[t]{2}{*}{349} & \multirow[t]{2}{*}{1257} & $102 b$ & $62 \mathrm{~b}$ & 164 & $51 \mathrm{~b}$ & $29 b$ & 80 & 76.5 & 45.5 & 122 \\
\hline & & & & 90.44 & 81.69 & 87.51 & 95.54 & 92.7 & 94.36 & 92.99 & 87.19 & 90.93 \\
\hline Control & 1161 & 513 & 1674 & $1365 \mathrm{a}$ & $498 a$ & 1749 & $1463 \mathrm{a}$ & $584 \mathrm{a}$ & 1891 & 1414 & 541 & 1955 \\
\hline $\mathrm{F}$ value & & & & $111.39^{\star *}$ & $68.59^{\star *}$ & & $218.03^{\star *}$ & $229.2^{\star \star}$ & & & & \\
\hline LSD at 0.05 & & & & 42.57 & 19.33 & & 34.15 & 13.16 & & & & \\
\hline
\end{tabular}

